\title{
Romani Literature(s) As Minor Literature(s) in the Context of World Literature: A Survey of Romani Literatures in French and Spanish
}

\section{Marina Ortrud M. Hertrampf}

marina.hertrampf@uni-passau.de

Professor of Romance Literature and Culture with a focus on France, University of Passau, Germany ORCID: https://orcid.org/0000-0001-8932-2193

Marina Ortrud M. Hertrampf is Professor of Romance Literature and Culture with a focus on France at the University of Passau, Germany. She is the author of a monograph on the interrelations of photography and the novel in French Postmodernism (2011), a study on the spatial dimensions in Spanish Corpus Christi plays (2018), and a small book on French graphic novels on the Arab Spring (2016). She runs the book series Aesthetics of Roma: Self and External Representations (AVM Munich).

\section{CDS Critical}

CRS Romani Studies 


\section{Abstract}

The article discusses the comparatively young form of written Romani literary self-expression as an example of "minor literature" in Deleuze and Guattari's sense. ${ }^{[1]}$ The focus here is on producing a classifying survey of the literary production of Romani writers in France and Spain, with the article outlining the different aesthetic fields and literary forms evident in French and Spanish Romani literature. The comparative approach reveals that despite regional and national differences, these minor literatures demonstrate several aesthetic similarities typical of Romani literature that could ultimately come to define the transnational, cross-border characteristics of Romani literature. Furthermore, I show that there are literary tendencies in contemporary Romani literatures that go beyond the usual forms of establishing literary self-expression in diasporic cultural productions or aesthetic appropriation of major society's literary traditions, so that Romani literatures in French and Spanish should, I argue, also be seen as part of world literature.

\section{Keywords}

- France

- Minor literature

- Romani literature

- Spain

- Transnational diaspora

- World literature

1 It is important to emphasize that the potentially offending implications of the evaluative use of the term "minor" is by no means hinted at in Deleuze and Guattari: The French "literature mineure" does not indicate lower aesthetic qualities or literary inferiority to majority literature but rather describes a literature produced by writers not (exclusively) belonging to the nation-state in which they live. At the same time, it should be mentioned that the term "small literature," in contrast to minor literatures, means literary expressions from small nations or/and in small languages like, for example, in Bulgarian, Estonian, or Luxembourgish (cf., Glesener 2012). 


\section{Introduction: What Is Romani Literature?}

What is Romani literature? The question seems quite simple but, in fact, is not. ${ }^{[2]}$ When talking about Romani literature, the first question to be asked is what is meant by "Romani" at all. Does the adjective refer to literary texts written in Romani, or is it an ethnic attribution concerning the authors of the texts in question? Strictly speaking, both, but let us start with the basics.

Every classification designation is a construct and is subject to ideological and literary-critical tendencies and trends. Just what one understands by the term "literature" changes over time, revealing, as the British literary scholar Terry Eagleton (1983) emphasized, close connections to the ideologies of societies. If ideologies determine what is to be regarded as literature, this applies increasingly to literary texts that, according to majority societal designations, show difference and divergence from majority literature, for example in the case of migrant and exile literature or, precisely, Romani literature(s), which also raises the highly complex question of ethnic identity. By the same token, however, the choice of the language could be used as a criterion: Romani literature would then be literature written in romani chib (Romani language).

Thus, the term "Romani literature" ultimately eludes a clear definition. Aware of this problem, I will apply the following pragmatic rule here: on the basis of an inter- and transmedial understanding of literature, the term "Romani literature" will include literary texts that were created by Romani authors, regardless of the language they were written in. Furthermore, anyone who explicitly presents themselves as Roma in paratexts, public forums (on the internet, in interviews, and so forth), or (socio-)political initiatives will be considered an author of Romani literature.

This form of ethnic labelling, of course, has a strong hegemonic and ethnocentric flavour and, moreover, carries with it the fundamental risk of overlooking the aesthetic quality of a literary work and instead foregrounding the fact that a representative of an ethnic minority has expressed themselves literarily in the majority language at all. This is probably one of the main reasons why José Heredia Maya (19472010), one of the best-known Spanish Romani poets, was opposed to this "ethnic exclusion" and stressed that there is no Spanish-language Romani literature: "Si escribimos en español hay una literatura española, con modulaciones personales, de estilo, de cultura ... pero no se puede hablar en sentido estricto de una literatura gitana si no hay una lengua que la soporte"[3] (Heredia Maya, in Rodríguez Mata 2000, 16). Although Heredia Maya's reasoning is understandable, it still seems legitimate to differentiate Romani literature within Spanish and other national literatures as a special form of literary expression. This article aims to outline further reasons for this beyond the criterion of the author's ethnic origin. ${ }^{[4]}$

2 For further discussions on what Romani literature does mean, see, for example, Djurić 2002, Eder-Jordan 1993, and Zahova 2014 and 2016 .

3 "If we write in Spanish there is a Spanish literature, with personal modulations in style, in culture ... but you cannot strictly speak of a Romani literature if there is no language that supports it" (author's translation).

4 See also Hertrampf and Blandfort 2011. 
Romani cultures are traditionally oral cultures. Until the middle of the twentieth century, writing especially in the majority languages - was regarded as an unacceptable cultural approach to the "majority society." In particular, writing about Romani society was perceived as taboo and led to exclusion from the society. The most striking example of this is the case of the Polish Romani author Bronisława Wajs, better known as Papusza, who was disregarded by Romani society due to the publication of her literary texts (Fonseca 2003).

Even if literary writing is still not accepted by all groups (and their members), there is increasing tolerance towards written literature from and about Roma within Romani society. This development is undoubtedly due to the acceptance of social change and the rapidly changing lives of Roma: if, today, the preservation of traditions is largely part of inner family life, and traditional life can only be conveyed through the stories of a passed generation of family members, the phenomenon of oraliture (Blandfort 2015, 76-100) becomes essential in order to preserve the collective memory.

Roma who write in the language of the majority culture are often not only linguistically and culturally assimilated but also socially integrated to some degree. It is noteworthy that in some of the works by these Romani authors there is a clear tendency towards the literary reconstruction of a rather old-fashioned, traditional Romani identity. In fact, there is a deliberate delimitation - or self-distancing, or othering from the culture in which they live in order to emphasize their ethnic and cultural alterity and thus to preserve their cultural independence as a diasporic community. In this respect, the emergence of written Romani literature is crucial to the creation of a diasporic consciousness. Thus, written Romani literature is an expression of self-confidence and empowerment and could to some degree be understood as a political act. In this respect the emergence of Romani literature plays an important role in the Romani self-perception as a transnational diaspora. ${ }^{[5]}$

If we assume that Romani literature is the cultural expression of a transnational diaspora, then it also becomes clear that it is a form of literature that has a strong cross-border character and is not only part of one specific national language majority literature. In order to adequately describe these two central characteristics of Romani literature as an aesthetic self-expression of a transnational diaspora, the concepts of minor literature and world literature seem particularly applicable.

5 The concept of (transnational) diaspora is understood in the sense of Vertovec 1997, 278, and Brubaker 2005, 12. For the understanding of Roma as a transnational diaspora, see Blandfort 2015, 37-61, and Hertrampf 2021. 


\section{On Minor Literature and World Literature: Some Remarks on Two Literary Concepts}

The notion of "minor literature" developed by Gilles Deleuze and Félix Guattari in their seminal 1975 book on Franz Kafka is perfectly suited to Romani literature that is not written in romani chib (Romani) but in the language of the majority. In fact, all three characteristics of minor literatures apply to Romani literature. First, a "minor literature," Deleuze and Guattari $(1983,16)$ claim, "is not the literature of a minor language but the literature a minority makes in a major language." French or Spanish Romani literatures, for instance, use the language of the majority without being completely identical to national literatures. In this respect, such literature addresses that they are both in between participation, integration, and assimilation on the one hand and issues of difference, othering, and delimitation on the other; therefore, Romani literary expression is always characterized by a certain degree of cultural and linguistic deterritorialization. Second, the idea that "everything in them [works of literature] is political" (Ibid.) also applies to Romani literature, which, in fact, can almost always be understood as non-violent resistance and sometimes - like in the case of Helios Gómez - even as subversive rebellion against the hegemonic and discriminatory behaviour of the majority. Romani literature thus becomes the "weapon" of the subaltern (Spivak 1995) in the struggle for recognition. Consciously or not, every Romani writer thus acts necessarily as a spokesperson for the minority.

At the same time, Romani literary production creates and reinforces diasporic consciousness and therefore illustrates "that everything has a collective value" (Ibid., 17). Indeed, the arguments of the third characteristic of minor literatures apply perfectly to many Romani authors:

In effect, precisely because talents do not abound in a minor literature, the conditions are not given for an individuated utterance which would be that of some "master" and could be separated from collective utterance. As a result the rarity of talents is, in fact, beneficial, and makes possible a conception of something other than a literature of masters: what the solitary writer says or does is necessarily political - even if others do not agree with him (Ibid., 17).

Literary expressions of the deterritorialized, transnational diaspora community in the language of the dominant majority thus always differ from national literatures and their aesthetic standards and literary canons. Following Kovacshazy $(2009,137)$, we must therefore understand Romani literature not only as a minor literature but also as an exemplary case of de- or polycentred notions of world literature. ${ }^{[6]}$

\footnotetext{
6 In order to describe the emergence of transnational and transregional forms of cross-border literatures, some critics prefer the term "global literature" (cf., e.g., Cooppan 2001). They argue that "globalization and world literature go hand in hand: they are both part of a larger cultural awareness of the processes of transculturation, inspiration, exchange, and engagement that govern our cultural, political, and economic lives. The attention they draw to these forms of circulation and exchange allows us to break out of our national, monolingual, or even purely inter-national models for the study of everyday life and of the history of literature - producing a new emphasis on local-global interactions, contact zones, regional formations, and multilingual literatures, among other things" (Hayot 2012, 224).
} 
Postcolonial as well as diasporic perspectives call into question the nation-based, proleptic emphasis of world literature, and the modernity of the world economic system that underpins it. Rather than a literary history comprised of national masterpieces that will be surpassed by transnational expressions, disaporic writers conjure a literary past marked precisely by the circulation, translation, and revision that Goethe identifies as the hallmark of the contemporary era of world literature (Frydman 2012, 233).

In his Introduction to a Poetics of Diversity (1996, 66), Glissant describes Roma as the quintessential people of diversity characterized by cultural métissage, world openness, and transgressive dynamism. Consequently, the literary self-expression of Roma is "without fixed abode" (Ette 2003) and is characterized by its aesthetic diversity; Romani literature is therefore paradigmatic of multiple cross-border "literatures on the move" (Ibid.). This follows Damrosch's concept of world literature as a mode of reading rather than a selection of canonical works:

World literature is ... always as much about the host culture's values and needs as it is about a work's source culture; hence it is a double refraction, one that can be described through the figure of the ellipse, with the source and host cultures providing the two foci that generate the elliptical space within which a work lives as world literature, connected to both cultures, circumscribed by neither alone $(2003,283)$.

Thus, Romani minor literature can be understood as world literature insofar as it configures a vision of the world, not only through diverse literary influences, transcultural hybridity, and cultural recycling, but also through revealing parallel developments across spatio-temporal, ethnic, and political spaces. Not least, Romani minor literature partakes of world literature through its ideological and political stance that is, its individual reinterpretation of normative facts and national standards.

\section{In-between Locality and Transnationality: Romani Minor Literatures}

To a much greater extent than other diasporic groups, Roma do not exist as one homogeneous ethnic group in the sense of a uniformly defined cultural community, but rather as a geographically disperse, inherently multicultural minority with more or less pronounced amalgam or hybrid identities (cf., Liégeois and Gheorghe 1995, 29). Transnational associations and interest groups such as the International Romani Union (IRU), existing from 1978 until 2018, the International Romani Writers' Association (IRWA), founded in 2002, or the Romani writers PEN Center show that the transnationality is also seen from the inside as an essential characteristic of a Romani diasporic nation. In literary texts, the concept of transnational belonging can often be found in the image of the world as home, combined with an existential connection to nature. This is the case in the poem "Por nacer gitano" (For having been born Gypsy) by the Spanish Romani poet Pedro Amaya (1993, 9), in which Amaya states: 


\author{
Por nacer gitano \\ $y$ de cuerpo entero, \\ el mundo es mi casa, \\ el cielo es mi techo, \\ la tierra es mi suelo. ${ }^{[7]}$
}

However, participation in the global network at respective nodes, which creates a sense of identity, is always in conflict with local integration into the majority society. In the everyday life of the different Romani groups, diaspora is more often felt as a part of everyday experience, rather than as a recognized concept. What is much more relevelant is the specific national and regional location, as well as linguistic and cultural integration. And yet Romani identities must be understood as a contradictory amalgam of integration and delimitation: locality and transnationality seem to merge into a diasporic "dual homeness" (Ben-Rafael 2013). This is explicitly articulated, for example, by Louise Helmstetter, a French Romani author who has been living in Alsace for generations. In an interview in which she was asked what her home country was, she replied: "L'Alsace... toute [sic] le monde!"[8] (Helmstetter 2012, 4:46-4:47).

In addition to regional localization, however, tendencies towards distinction and separation emphasizing the alterity of Romani culture can be observed as well: "Que se den cuenta de que somos hombres. $Y$ gitanos, pero gitanos de verdad"[9] (Giménez Mendoza 1969, 114). Because of this hybrid identity between transnationality and locality, between participation in the culture and language of the surrounding majority society and self-confident othering, there is neither one single Romani culture nor one single Romani literature. ${ }^{[10]}$ Rather, a large number of minor (Romani) literatures can be assumed, which can be thought of as a rhizome, to use Deleuze and Guattari's term (1980, 36-37), that is, as a network that has diverse nodes at which connections, links, and exchanges can take place between the transnationally dispersed communities.

Despite the peculiarities of the different minor (Romani) literatures, they all possess common characteristics, through which they form a cross-border network within world literature. Accordingly, the connecting characteristics of the minor (Romani) literatures can be understood in Wittgenstein's sense (1953, sections 66-71) as "family resemblances," that is, as tendencies and characteristics on an aesthetic level that can be regarded as a similar "handwriting" connecting all works by Romani authors.

\footnotetext{
7 For having been born Gypsy / and with a whole body, / the world is my home, / Heaven is my roof, / the earth is my soil (author's translation).

8 "Alsace... everywhere in the world!" (author's translation).

9 "Let them realize that we are men. And Gypsies, but real Gypsies" (author's translation).

10 The idea of literary plurality has been strengthened by Cécile Kovacshazy 2009, 136.
} 


\section{Aesthetic Fields and Literary Forms of Romani Minor Literatures}

A comparison of the works of contemporary Romani authors who are writing in romance languages reveals certain stylistic and aesthetic similarities. ${ }^{[1]}$ These include the tendency to employ vernacular language, a comparatively high level of dialogue, and the integration of Romani words. Many works by Roma are performative and/or hybrid in character. The preference for performative narrative forms can be traced back to long-standing traditions of oral literature (magic legends, myths, fairy tales) as well as oral history building, that is, the oral transmission of collective memory, founding origin myths, and life experiences to maintain and strengthen group identity. Music and dance, elements of Romani cultures that constitute identity, and whose performative character is reflected in various forms of intermediality and combining media, play an important role in almost all literary texts by Romani authors. The presence of music and dance also reflects the creative urge to (re)create written literature in order to merge artisticaesthetic traditions of oral Romani literature with elements of the majority written literature.

As with all emerging, comparatively new minor literatures, different phases of literary self-expression can be found in terms of aesthetics, often leading from initial attempts at writing through literary appropriation to literary emancipation. Of course, as with all such classifications, these are purely constructed ideal types. The aesthetic fields and literary forms presented below can thus be regarded as interwoven and even dynamic categories: there are parallels and overlaps between the phases, and individual authors go through different phases simultaneously or successively, often entailing several literary fields, forms, and models. Generally speaking, the following four major literary fields, forms, and models can be traced.

In the first category are works whose creators are literary autodidacts, who consciously raise their voice in the written majority language and want to be perceived explicitly as "authors." In a way, this form of literary expression resembles popular folkloric art forms, which is by no means to be understood as a judgement on quality, but rather as a widely used form of aesthetic expression by emerging art forms. With these works, the writing process originates from the desire to transfer a sense of creative surplus into the documentation of group-specific collective knowledge. In many cases, these are forms of oraliture, that is, texts that are strongly linguistically based on the oral language and thus have a function in documenting the Romani oral literary tradition and forming a sense of identity. Even if such literary production can in some cases lead to the exclusion of authors from the community, they generally become cultural productions that serve to strengthen diasporic group cohesion.

A large number of Romani authors have clear literary and aesthetic ideas, which they give expression to in narratives in the tradition of the realistic novel of the nineteenth century, which often follows a popular aesthetic narrative pattern. As a rule, these are narrative texts with a more or less pronounced

11 To work out transnational stylistic and aesthetic similarities of all Romani literatures was the aim of the Scientific Network's project "Aesthetics of the Roma: Literature, Comic and Film of Roma" (2017-2020), founded by the German Research Foundation (DFG) (https://gepris.dfg.de/gepris/projekt/359840883). The results are published in Hertrampf and von Hagen $2020 \mathrm{~b}$. 
(auto-)biographical or docufictional character. Looking back at the past is a dominant theme, with narratives often focused on family histories or the author's own childhood and youth in the times of Nazi persecution. In many cases, these are also intergenerational stories of suffering and social advancement in the tradition of sentimental narratives, combined with folklore and regional elements that clearly engage the reader's sympathy for Romani protagonists. These works can at times also take on features of littérature engagée (committed literature). ${ }^{[12]}$ The texts in this category are mostly aimed at readers of the majority society, which can be seen, for example, in the explanations of customs and traditions, values, and taboos.

Some writers of Romani descent do not only see themselves as literary mouthpieces of the minority but as emancipated writers within the surrounding majority societies. Thus, their works break free from thematic self-references and represent instead a form of modern aesthetics of minor literatures, as their authors not only have a clear aesthetic awareness of what constitutes literature and its poetic surplus but also an extensive knowledge of literary patterns and aesthetic processes from that majority literature’s modernity.

The fourth category can be described as an aesthetics of emancipation and demarcation. Works from this phase are inscribed in the contemporary literary field of majority societies. The authors are part of the literary field and can take a position accordingly with their works, co-write or continue to write according to trends (postmodern aesthetics, gender aspects and diversity, bio-documentation, and so on), or deliberately differentiate themselves from these trends. Authors of these works seek success not only aesthetically but also commercially. Even if these literary productions have no explicit thematic reference to the minority group and go unmarked (at least aesthetically) as part of the literary production of the majority societies, they often display subtle subversions of existing literary forms or develop new types by blending elements of different literary conventions and traditions.

The following two sections illustrate how these four major categories of developing Romani literature are reflected in French and Spanish literary productions of Romani authors.

\section{French Romani Literature}

The phenomenon of French Romani literature is relatively new, emerging just after the Second World War when Matéo Maximoff (1917-1999) published his first novel, Les Ursitory (The Ursitory), in 1946. Since the 1990s in particular, more and more publications by Romani authors have appeared in France, though with only a very small number of works being published in nationally recognized publishing houses that provide access to a larger market. French Romani literature therefore remains - mostly for economic and structural reasons, concerning publication and distribution - just as "invisible" as many members of the minority themselves.

12 For the political elements of Romani writing, see Toninato 2014. 
Until now, around 20 writers who identify as Roma have published literary texts in France (Blandfort 2019). It should also be noted that even if lyrical works significantly outnumber narrative texts, it is nevertheless narrative texts that have appeared in print with major national publishing houses - with a few notable exceptions, such as Alexandre Romanès' poetry book Paroles perdues (Lost words, 2004).

An overview of the overall production of narrative texts by French Romani authors shows a clear dominance of autobiographical and semi-fictional texts with strong ethnic self-reference, in which the view of the past is predominant and the everyday life of nomadic Roma is depicted. ${ }^{[13]}$ It also shows that the vast majority of the authors are literary autodidacts and that many narrative texts were created in co-authorship with members of the majority society, quite often in the form of oraliture. With the (quite political) goal of drawing attention to the painful past and making Roma visible as a transnational diaspora culture, these texts are very often addressed to majority society, which can be seen, for example, in the tendency to provide explanations of Romani words and customs.

Examples of these are the fragmentary family biographies Où vas-tu, manouche? Vie et mœurs d'un peuple libre (Where are you going, Gypsy? Life and customs of a free people) (1982) by Joseph Doerr (19021986) and Sur ces chemins où nos pas se sont effacés (On these paths where our steps have faded) (2012) by Louise "Pisla" Helmstetter (1926-2013), Lick Dubois' trilogy Scènes de la vie manouche (Gypsy life scenes) (1998, 2003, and 2007), and Miguel Haler's autobiography Le guitariste nomade (The nomad guitarist) (2005). The case of Je suis Tzigane et je le reste (I'm a Gypsy, now and forever) (2013) by Anina Ciuciu and co-authored with the non-Romani journalist Frédéric Veille is a little different: Ciuciu's report on her family's migration from ex-communist Romania to France and her final success in studying law at France's renowned Sorbonne University in Paris has a double purpose. On the one hand, it draws the attention of non-Romani readers to the particular difficulties of integration faced by young Romani women. On the other hand, Je suis Tzigane et je le reste has a strong appellative function and is aimed at young Romani women who are in the same situation, encouraging them to take a new, self-confident path towards achieving similar success.

There are also many more or less fictional stories about Romani protagonists, the majority of which are aimed at a majority society readership. Often, stories such as Sandra Jayat's La longue route d'une Zingarina and La Zingarina ou l'herbe sauvage (The long road of a Zingarina, and Zingarina or wild grass) (2010) or Miguel Haler's La Route des gitans (The Gypsy route) (2008) display features of auto- and docufiction. While reference to the past dominates the vast majority of narrative texts, an exception is Lick Dubois' Romanestan: L'île du peuple rom (Romanestan: The island of Romani people) (2010). The novel has a utopian character, as is evident in its stance towards efforts to build a Romani state.

The increasing acceptance of written Romani literature goes hand in hand with the recognition of literature as a legitimate form of media for preserving and passing on collective memory. Some Romani authors, therefore, deliberately write for a younger generation who no longer know the traditional ways of life and who have little or no command of Romani language. This applies to authors who, like Roberto Lorier in 
his Saga tsigane: Pâni et le peuple sans frontières (Gypsy saga: Pâni and the people without borders) (2010), present the origin myths of Roma and their emigration from India in literary narratives, or those like the linguist Vania de Gila-Kochanowski (1920-2007), who write down traditional oral myths, legends, and fairy tales, like in Le roi des serpents et autres contes tsiganes balto slaves (King of snakes and other Balto-Slavic Gypsy tales) (1996) or La prière des loups: Récits tsiganes (The prayer of the wolves: Gypsy stories) (2005). Gila-Kochanowski's mostly bilingual works always have a strong linguistic, didactic impetus and also serve, among other things, to present Romani to young Roma as well as to non-Roma.

The first movements towards aesthetic emancipation, including thematic self-reference and a clear enrolment in French majority literature, are particularly pronounced with Miguel Haler. His more recent works such as the children's book Le grand voyage de Loa (Loa's great journey) (2010), the animal history Les mémoires d'un chat de gouttière (The memories of a gutter cat) (2011), or Moi, Joseph l'Alsacien: Soldat français de la Grande Guerre (Me, Joseph the Alsatian: French soldier of the Great War) (2014) have no thematic relation to the minority group and constitute an unmarked part of literary production in France.

\section{Spanish Romani Literature}

Cultural practices of Roma in Spain have become part of the majority culture much more than in other countries. This influence has played a major role in the construction of Spanish identity in general, and the proportion of Spanish Roma who are completely assimilated into majority society in terms of language, and at least selectively and partially assimilated in terms of language and culture (Bernecker 2007, 295), is very large in comparison with other European countries. Nevertheless, Spanish Roma are still perceived as "other within" or "domestic/internal other" (Boyarin 1994; Nord 2006).

As in other European countries, written Romani literature in Spain is a fairly recent development, emerging only at the beginning of the twentieth century (Hackl 1987; Hertrampf 2011; Hertrampf and Blandfort, 2011). The Sevillian poet, artist, and revolutionary Helios Gómez (1905-1956) is generally considered the first Romani author to write in Spanish (Tjaden 1998). Not least because of Franco's reprisals against all Spanish minorities, any literature penned by Roma was rendered virtually nonexistent. A certain exception, however, was flamenco poetry, although it should also be noted that, apart from José Heredia Maya, only a few Romani flamenco poets have achieved national recognition. ${ }^{[14]}$ But even after the transición (that is, the period of transition to democracy after the death of Franco in 1975), literary productions by Roma remained virtually invisible. A turning point can only be seen from the 1990s onwards. Still, Spanish-writing Roma who, as mediators, deliberately cross cultural-ethnic boundaries between the surrounding society and their own group, continue to be the exception. ${ }^{[15]}$

In contrast to French Romani literature, contemporary Spanish Romani literary production is almost exclusively concentrated on narrative texts, although it, too, had its origins in lyrical works. Furthermore, literary work

14 On Heredia Maya, see Hancock, et al., 1998, 37-39.

15 For more detailed surveys, see Hertrampf 2011, 2019; and Hertrampf and Blandfort, 2011. 
and political engagement are much more closely linked. Joaquín Albaicín (born 1965) is undoubtedly the bestknown and most productive Spanish Romani author of the present-day. He is a founding member of the IRWA and, in addition to his literary activity, works as a socially and politically active journalist. Spanish Romani authors of younger generations like Sally Cortés Santiago, Marcos Santiago Cortés, and Núria León de Santiago appear confidently in public and on social networks as Gitan@s, and are involved in various nongovernmental organizations and Romani associations for the empowerment of Roma in general and Romani women in particular. With their commitment to being seen as Spaniards as well as Roma, the road seems paved for a greater visibility of literary works by Spanish authors with Romani backgrounds in the future.

Albaicín comes from a well-known Spanish Romani artist family: his mother and great aunt were celebrated flamenco dancers and his grandfather the successful torero Rafael Albaicín. In his esoteric narrative works, Albaicín deals with Romani mythology and traditional Romani culture. In Gitanos en el ruedo: El Indostán en el toreo (Gypsies in the ring: Hindustan in bullfighting) (1993), La serpiente terrenal (The earthly serpent) (1993), En pos del sol: Los gitanos en la historia, el mito a la leyenda (In pursuit of the sun: Gypsies in history, myth to legend) (1997), and the storybook La estrella de plata (The silver star) (2000), Albaicín presents the Romani origin story in fiction by incorporating different founding myths. In general, his prose texts are characterized by the oscillation between non-fiction and narrative storytelling, reality and fiction. This is particularly evident in his Diario de un paulista (Diary of a São Paulo resident) (1995), which is a form of diary that traces the life story of his grandfather in a semi-documentary way.

Much like Albaicín, Sally Cortés Santiago, in her debut novel Cuando callan las estrellas (When the stars are silent) (2018), works with one of the founding legends of the Roma, whom she calls "Gypsios," then combining this with a dystopian vision of a Third World War. Ultimately, at the centre of the novel is the forming of the identity of the 21-year-old protagonist, Serena, who has to assert herself in a disrupted world that exists between tradition and progress, right and wrong, hate and love.

The lawyer Marcos Santiago Cortés (born in 1972), who works in Córdoba, is also the author of four novels, although he only explicitly deals with Romani culture in Gitanófilo (Gypsiphil) (2018), a kind of homage to his Romani roots. His other novels follow common literary patterns of contemporary (Spanish) fiction. On the one hand, he works in a semi-documentary style, dealing with Spain's recent history. His Amor de Olivo (Olive love) (2013) throws a critical light on the exploitation and discrimination of women in rural Spain at the beginning of the twentieth century, which is also the setting of his novel Rivera de Primo (2015). Santiago Cortés has also published a novel called La nueva Jerusalén (The new Jerusalem) (2019), which is somewhere between a social novel and a crime novel, and deals with drug trafficking and procurement crime in the disadvantaged neighbourhoods of Cordoba.

Finally, Núria León de Santiago should be mentioned: not only is she the first female Spanish Romani author to represent her Spanish Romani authorship in an unusually confident manner, but her debut novel - El ángel de Mahler (Mahler's angel) (2014) - can be described as an outstanding example of an aesthetics of emancipation. ${ }^{[16]}$ El ángel de Mahler uses aesthetic patterns of majority literary writing and 
thus inscribes itself in the field of contemporary Spanish literature, in which biofictions and docufictions belong to the fictional mainstream. By placing Gustav Mahler, that is, a historical, non-Gitano personality, at the centre of her biofiction and only presenting marginal thematic references to the minority group, León de Santiago emancipates herself from self-referential forms of aesthetic expression commonly used by Romani authors and thus distances herself from the category of minority or "Gitano" literature. At the same time, the novel is a plea for tolerance and acceptance of individual and collective diversity, as well as for a return to the greatest of human values, which is an unconditional love that overcomes all differences. In this way, El ángel de Mahler can be read as an attempt to develop a transcultural as well as trans-ethnic (Romani) aesthetic.

\section{Conclusion: Romani Minor Literatures on their Way to World Literature}

This article began by asking a very general question: What is Romani literature? I have argued that the ambiguous term describes literary texts written in Romani or any other national language by authors of Romani descent or who consider themselves as Roma. Furthermore, it could be shown that there is not one Romani literature, but that the differences within the numerous groups of the minority, as well as the multiple linguistic, literary, and cultural affiliations with or orientations towards established literatures of majority societies, have lead to the emergence of various minor literatures, and that these minor literature show common peculiarities in form and content that can be regarded as characteristic of Romani literature. Thus, in fact, there is a wide range of Romani minor literatures all over the globe that nevertheless remain rather invisible. The invisibility of Romani minor literatures is the result of several factors: a limited number of works of Romani literature, a certain lack of confidence of some Romani authors and their Romani reading public, and structural problems concerning the recognition of Romani literature by the authorities and institutions that dominate literary fields and book markets within majority societies.

The overview of the literary production of French and Spanish Romani authors presented here has shown, however, that there is a growng tendency towards self-confident writing and performance among these Romani authors. Therefore, it can be said that today's Romani minor literatures have taken the first step towards taking their place in the expanding global scope of world literature. 


\section{References}

Amaya, Pedro. 1993. Le monde est ma maison (The world is my home). Céret: L'Aphélie.

Ben-Rafael, Eliezer. 2013. "Diaspora." Current Sociology 61 (5-6): 842-61.

Bernecker, Walther L. 2007. "Von der Repression zur Assimilation: Zigeunerpolitik im Spanien des 20. Jahrhunderts." In Zwischen Erziehung und Vernichtung: Zigeunerpolitik und Zigeunerforschung im Europa des 20 Jahrhunderts (Between education and annihilation: Gypsy policy and Gypsy research in 20th century Europe), edited by Michael Zimmermann, 278-95. Stuttgart: Steiner.

Blandfort, Julia. 2015. Die Literatur der Roma Frankreichs (French Romani literature). Berlin: de Gruyter.

. 2019. "The Literature of the Sinti and Roma in France: On 'Nomadic' Identities." RomArchive. https://www.romarchive.eu/en/literature/literature-countries-and-regions/romani-literature-france.

Boyarin, Jonathan. 1994. “The Other Within and the Other Without." In The Other in Jewish Thought and History: Constructions of Jewish Culture and Identity, edited by Laurence J. Silberstein and Robert L. Cohen, 423-52. New York: New York University Press.

Brubaker, Rogers. 2005. “The 'Diaspora’ Diaspora.” Ethnic and Racial Studies 28 (1): 1-19.

Cooppan, Vilashini. 2001. "World Literature and Global Theory: Comparative Literature for the New Millennium." Symploke 9 (1-2): 15-43.

Damrosch, David. 2003. What Is World Literature? Princeton: Princeton University Press.

Deleuze, Gilles, and Félix Guattari. 1980. Capitalisme et schizophrénie: Mille plateaux (A thousand plateaus: Capitalism and schizophrenia). Paris: Minuit.

—. 1983. "What Is a Minor Literature?" Mississippi Review 11 (3): 13-33.

Djurić, Rajko. 2002. Die Literatur der Roma und Sinti. Berlin: Edition Parabolis.

Eagleton, Terry. 1983. Literary Theory: An Introduction. Minneapolis, MN: University of Minnesota Press.

Eder-Jordan, Beate. 1993. “Geboren bin ich vor Jahrtausenden...”: Bilderwelten in der Literatur der Roma und Sinti. Klagenfurt: Drava.

Ette, Ottmar. 2003. Literature on the Move. Amsterdam: Rodopi.

Fonseca, Isabel. 2003. Enterrez-moi debout: L’odyssée des Tziganes (Bury me standing: The Gypsy odyssey). Paris: Albin Michel.

Frydman, Jason. 2012. "World Literature and Diaspora Studies." In The Routledge Companion to World Literature, edited by Theo D’haen, David Damroch, and Djelal Kadir, 232-41. London and New York: Routledge.

Giménez Mendoza, Luis. 1969. “Problema resuelto." Pomezia 43: 113-14.

Glesener, Jeanne E. 2012. "On Small Literatures and Their Location in World Literature: A Case Study on Luxembourgish Literature." Interlitteraria 17: 75-92.

Glissant, Éduard. 1996. Introduction à une poétique du divers (Introduction to a poetics of diversity). Paris: Gallimard.

Hackl, Erich. 1987. Zugvögel seit jeher: Freude und Not spanischer Zigeuner (Migratory birds since forever: Joy and misery of Spanish Gypsies). Vienna: Herder. 
Hancock, Ian F., Siobhan Dowd, and Rajko Djurić, eds. 1998. The Roads of the Roma: A PEN Anthology of Gypsy Writers. Hatfield, UK: University of Hertfordshire Press.

Hayot, Eric. 2012. "World Literature and Globalization.” In The Routledge Companion to World Literature, edited by Theo D'haen, David Damroch, and Djelal Kadir, 223-31. London and New York: Routledge.

Helmstetter, Louise “Pisla." 2012. "Pisla Helmstetter et la vie des tziganes en Alsace." Alsace 20. https://www.youtube.com/watch?v=N-OtplpOiYc

Hertrampf, Marina Ortrud M. 2011. “España también es gitana': Literatur spanischer Roma.” Hispanorama 132: $66-77$.

. 2017. "Roma-Gesellschaften im Spannungsfeld von selbstgewählter Abgrenzung und fremdbestimmter Ausgrenzung am Beispiel französischer Roma-Literatur.” In Parallel- und Alternativgesellschaften in der Gegenwartsliteratur (Parallel and alternative societies in contemporary literature), edited by Teresa Hiergeist, 145-168. Würzburg: Königshausen \& Neumann.

_ . 2019. "Roma Literature in Spain: An Overview." RomArchive. https://www.romarchive.eu/en/literature/ literature-countries-and-regions/literature-spain

- 2020. "Der 'andere’ Mainstream: Núria León de Santiagos biofiktionaler Roman El ángel de Mahler." In Ästhetik(en) der Roma: Selbst- und Fremdrepräsentationen (Romani aesthetic(s): Self and external representations), edited by Marina Ortrud M. Hertrampf and Kirsten von Hagen, 97-115. Munich: AVM.

—. 2021. "Roma als 'andere’ transnationale Diaspora." Quo vadis Romania? 56: 117-33.

Hertrampf, Marina Ortrud M., and Julia Blandfort, eds. 2011. Grenzerfahrungen: Roma-Literaturen in der Romania (Borderline experiences: Roma literatures in Romania). Berlin: LIT.

Hertrampf, Marina Ortrud M., and Kirsten von Hagen, eds. 2020a. Ästhetik(en) der Roma: Selbst- und Fremdrepräsentationen (Romani aesthetic(s): Self and external representations). Munich: AVM.

—. 2020b. "Ästhetik(en) von Roma: Eine thematische Einführung." In Ästhetik(en) der Roma: Selbst- und Fremdrepräsentationen (Romani aesthetic(s): Self and external representations), edited by Marina Ortrud M. Hertrampf and Kirsten von Hagen, 7-20. Munich: AVM.

Kovacshazy, Cécile. 2009. "Littératures romani: Cas exemplaire de la literature-monde? (Illustrations à partir d'auteurs autrichiens).” Études tsiganes 36 (1): 136-145.

Liégeois, Jean-Pierre, and Nicolae Gheorghe. 1995. Roma/Gypsies: A European Minority. London: Minority Rights Group.

Nord, Deborah Epstein. 2006. Gypsies and the British Imagination, 1807-1930. New York: Columbia University Press.

Rodríguez Mata, Lydia. 2000. “José Heredia Maya.” Gitanos: Pensamiento y cultura 5: 16-17.

Spivak, Gayatri Chakravorty. 1995. “Can the Subaltern Speak?” In The Post-colonial Studies Reader, edited by Bill Ashcroft, Gareth Griffiths, and Helen Tiffin, 24-28. London and New York: Routledge.

Tjaden, Ursula, ed. 1998. Helios Gómez. Valencia: Ivam Centre Julio González.

Toninato, Paola. 2014. Romani Writing: Literature, Literacy and Identity Politics. London and New York: Routledge.

Vertovec, Steven. 1997. “Three Meanings of 'Diaspora' Exemplified among South Asian Religions.”

Diaspora: A Journal of Transnational Studies 6 (3): 277-99.

Wittgenstein, Ludwig. 1953. Philosophische Untersuchungen (Philosophical investigations). Berlin: Suhrkamp. 
Zahova, Sofiya. 2014. History of Romani Literature with Multimedia on Romani Kids' Publications. Sofia: Paradigma.

. 2016. "Romani Literature: Historical Developments and Challenges of Internationalization."

In Roma Culture: Myths and Realities, edited by Elena Marushiakova and Vesselin Popov, eds, 81-126.

Munich: Lincom Academic. 